\title{
IS THE LOSS OF VERNACULAR ARCHITECTURE REVERSIBLE? THE CASE OF LAHUN VILLAGE IN EGYPT
}

\author{
M. Korachy ${ }^{1}$, \\ ${ }^{1}$ Founder of Mariam Korachy Architects, mariamkorachy.com - mariamkorachy@ gmail.com
}

Comission II - WG II/8

KEY WORDS: Lahun Heritage, Vernacular, Architecture, Intangible, Reversible loss, Egyptian village, Tunis village.

\begin{abstract}
:
In Fayoum, the largest oasis in the Egyptian western desert, the modern Lahun village was developed close by the ancient mud-brick Lahun Pyramid in the 19th Century. The architecture of Lahun village followed its ancestors' architecture. Until 2003, a mix of mud and stone vernacular houses were dominant in the village. In 2010, 35\% of the houses at Lahun main street, which leads to the pyramid site, were of mud brick/stone houses, the rest was replaced by high-rise concrete buildings. By 2019, little traces of the traditional vernacular dwellings survived a massive movement to concrete construction. In the last 15 years, the skyline of the village has completely transformed. Lahun's loss of its vernacular architecture is not an exception, except in one case: Tunis village where a pottery school for locals, started 30 years ago, to change the future of Tunis, where traditional architectural techniques have taken an important place in contemporary constructions. What are the local needs when they decide to replace their traditional houses with concrete? What is the impact of the pyramid's recent re-opening on the village? What should be learned from Tunis village? Could what remained from the aspects of the Lahun vernacular heritage be used to reverse the loss of the tangible architectural aspects? Is new architecture that is sympathetic to the traditional vernacular character of the village a solution?
\end{abstract}

\section{INTRODUCTION}

\subsection{The Unique Location of Historic Lahun Village}

Charles Rochfort Scott, in his book 'Looking down across the Fayoum', in 1836 wrote “...El Lahun, The gorge, which serves as the link, connecting the cultivation of the Fayoum with that of the valley of the Nile...".

The Lahun village is located in the far East South of the Fayoum oasis, a large depression in the Egyptian Western Desert (a total area of 4,000 square $\mathrm{km}$ and includes approx. 160 villages). The town is 19 kilometers southeast of the Fayoum city and 120 kilometers from Cairo.

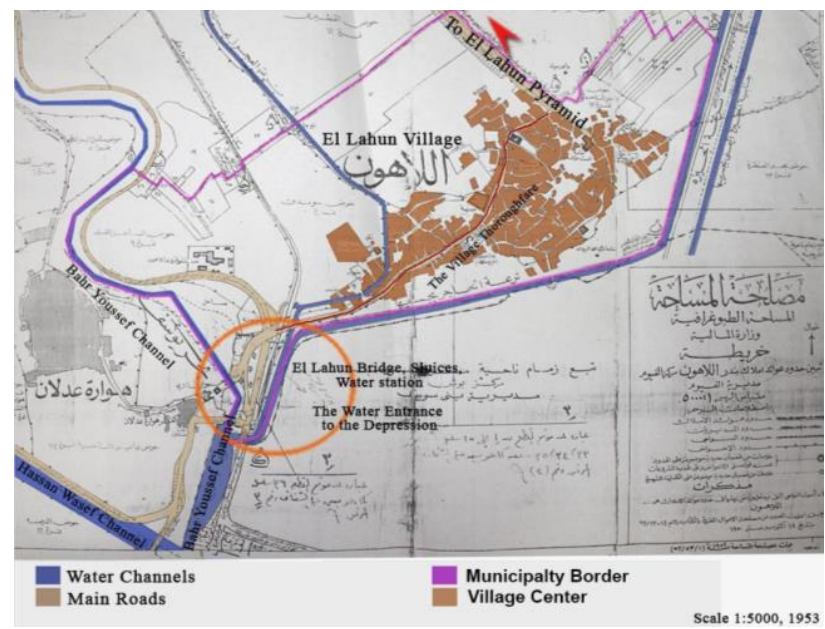

Figure 1. The Egyptian General Survey Authority Map of the Lahun Gap, (scale 1:5000, 1953).
The depression has been inhabited since the Stone Age, but really came into its own during the middle Kingdom of Ancient Egypt. Many valuable and important monuments and archeological sites are concentrated in the depression. Furthermore, the existence of the big salty lake of Qaroun gives the area a splendid special character. Fayoum was described in history as 'the garden of Egypt'.

As Ancient Egyptians called it, the village name 'Lahun' or 'LeHone', means the mouth of the lake, or the mouth of the flood. A fault in the plateau bordering the depression allowed the waters of the river Nile and its overflow rush via Bahr Yusuf through El Lahun Gap. Since Lahun is the water entry point to Fayoum, it is one of the most important villages in the depression that always had a significant geographical position throughout history.

\subsection{Lahun Monuments and Sites}

The village is a historic area where important monuments stand: The Lahun Pyramid, archeological site of the pyramid builders city and the ancient water barrage, Gisr Gadallah ${ }^{1}$.

Nearly 4000 years ago, the Lahun Pyramid was built in mud brick during the 12th dynasty as well as its builders' city. The mud-brick pyramid was discovered by Flinders Petrie ${ }^{2}$ in 1889.

\footnotetext{
* Corresponding author.

1 Gisr Gadallah dyke is a massive twisting earthwork construction that is thought to be part of the original barrage built in the 12th dynasty to divert water into Fayoum. Today, the dyke is in a deteriorated state and needs urgent protection and preservation. The road above the dyke is paved with asphalt. Due to the urban expansion, concrete constructions have been built on the side of the road on agricultural lands.

2 Professor Sir William Matthew Flinders Petrie FRS , 1853 - 1942), known as Flinders Petrie, was an English Egyptologist and a pioneer of systematic methodology in archaeology. Excavated at many of the most important archaeological sites in Egypt, such as Naukratis, Tanis, Abydos and Amarna, Lahun.
} 
In June 2019, the mud brick pyramid was opened to the public, for the first time.

In May 2009, Near the pyramid, archaeologists found an approximately 5,000-year-old tomb, an indication that the site held religious significance a millennium earlier than previously thought. The discovery changed a prior archaeologists' belief that the site only dates back to 12th dynasty pharaoh Senusret II who ruled 4,000 years ago. The existence of this tomb is very significant since it explains that Senusret II, the builder of the pyramid, is not the founder of this site. It must have had religious significance in ancient Egypt, and that explains why the pharaoh chose the site to build his pyramid.

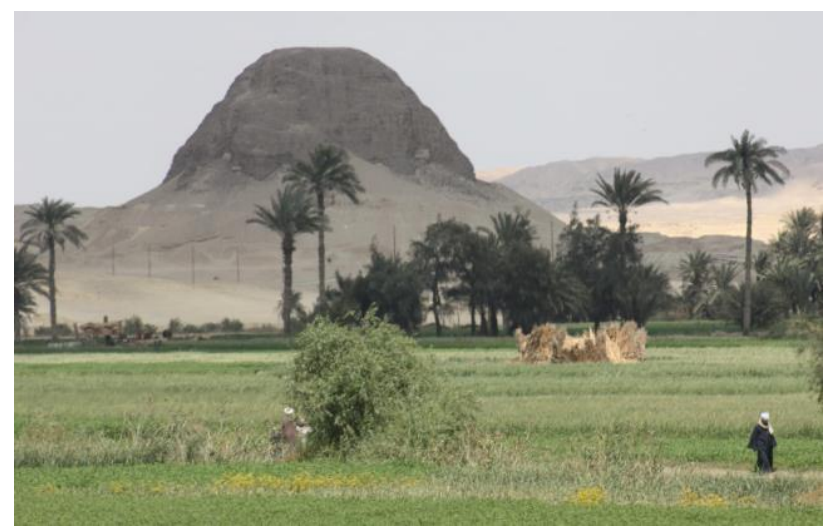

Figure 2. View of the Lahun pyramid from Lahun village, (C) Author Image Copyright (2003).

Throughout the history of studying the ancient Egyptian civilization, historians relied on studying hundreds of remaining monumental buildings built by stone such as temples and pyramids to uncover the Pharaohs' lives. On the contrary, rare information was available on the daily life of the local population because their mud brick dwellings and settlements did not survive. Their vernacular constructions were easily lost. However, the discovery of the ancient Kahun (Lahun) workers village, in the vicinity of Lahun pyramid, allowed an understanding of the everyday life of local ancient Egyptians.

The modern Lahun village until recently was the only available entrance to reach the Lahun historic site. The entire main street of the village and Gisr Gadallah dyke had to be crossed in order to reach the pyramid complex.
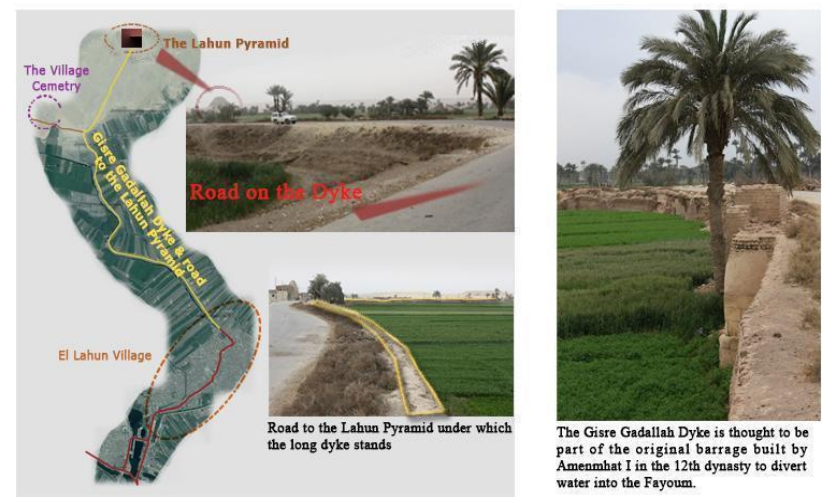

Figure 3. Google map image, 2009, View of Gisr Gadallah barrage, from the village and to the pyramid, (C) Author Image Copyright (2010).

\subsection{Old Image of the Village}

Nothing is more like one Egyptian village than another Egyptian village...the same people living the same life have built the same kind of villages. (Ayrout, 1930).

The research work and documentation of the Egyptian vernacular architecture is rare and in most cases is conducted by anthropologists. Written material precisely on Lahun modern village is sparse except what was documented about the monuments of the village.

Based on the unique fieldwork of the anthropologist Winifred S. Blackman which was concentrated in Asyout and Fayoum regions, particularly the area around Lahun village, a past image could be drawn of the village in the 1920s. The village was an isolated whole, outside of which even neighbours are strangers. Customs, manners and prohibitions handed down from ancestors and the community laws governed the acts and pleasures of all inhabitants. The village lives its own selfcentered life. For a peasant, its nationality belongs to his or her village $^{4}$.The general description of peasant houses by Henry Habib Ayrout in the 1930s and 1940s, the architect Hassan Fathy in the 1960's and the study of the Egyptian anthropologist Nessim Henry Henin on the hamlet of Mari Girgis, in Upper Egypt, in the 1970s, all of which have described very similar features of the Egyptian villages to the one of Blackman in the $1920 \mathrm{~s}^{5}$. Historically, the geographical isolations by the natural barriers of Egypt by deserts and seas, enabled its inhabitants to preserve their characteristic features. Especially their beliefs, religious norms, social customs and crafts, which were almost unchanged from the time of Ancient Egypt. This continues to be a solid heritage in Egyptian villages.

Lahun is no exception. Seen from the outside, it is an earthy mass compact, above which greenery rises, with few white plastered buildings, bigger houses or a large pigeon house. The interior of the village was picturesque. The urban fabric of the village was formed of narrow unnamed streets, houses were wall to wall, forming closed facades of grey adobe, which were 5-10 meters wide and 3 meters high.

Usually, groves of palm trees surrounded the village and vines grew among the houses and in their courtyards to form a shelter from the heat. Beautifully, a high contrast existed between the evergreen villages and the sandy yellow desert. In large villages like Lahun, one or maximum two broad streets worked as the main road in the village, where vendors used to do their trading with goods displayed on handcarts.

The peasants' dwellings were usually small simple constructions, built of mud bricks and plastered with adobe. Mud plastering filled the gaps between the bricks to protect the houses from the heat in summer and rainwater in the winter. Windows were small openings, most of the time unglazed with wooden shutters. The majority of the houses had passages covered with a light structure of wood or a middle courtyard. Each house, generally had as rectangular plan, constituted of: A courtyard, one or two or more rooms (depending on the wealth of the family and its size), a stable for the animals which was an essential element in peasants daily life, storage spaces for the straw and sometimes a pigeon house or two.

\footnotetext{
Ayrout, 2005

Blackman, 2000.

Ayrout, 2005
} 
Peasants' houses were very suitable for the Egyptian climate, the only thing lacking to make them pleasant was a lack of hygiene. The culture of Egyptian peasants dealt with the house as a place for cooking and sleeping but people spent most of their time outdoors. The interior of the rooms was often small and dark.

Houses structure would depend on whether it was inherited or not. In fact, sons would divide the house after the death of the father in equal parts. They would live in the house together or they might divide it physically with walls and create for every share a separate entrance. However, the house may be extending vertically with the growth of the family. Usually, one or two rooms are added on the roof of the house and the staircase is constructed from the internal courtyard.

Vernacular building techniques were the result of a long process of trial and error, and experiences inherited from ancestors. There were no written rules. Therefore, the decision of the depth of the foundations, the thickness of the walls as well as the choice of palm-trees trunks size, for the lintels and beams, depended on the peasant's spontaneous sense and experienced eye.

Mud brick making was a fundamental industry in the village. Most of the peasants' dwellings and even some of the higherclass houses are built with these mud bricks. Everyone knew how to make mud bricks therefore the fabrication was a teamwork process that included men, women and the whole family.

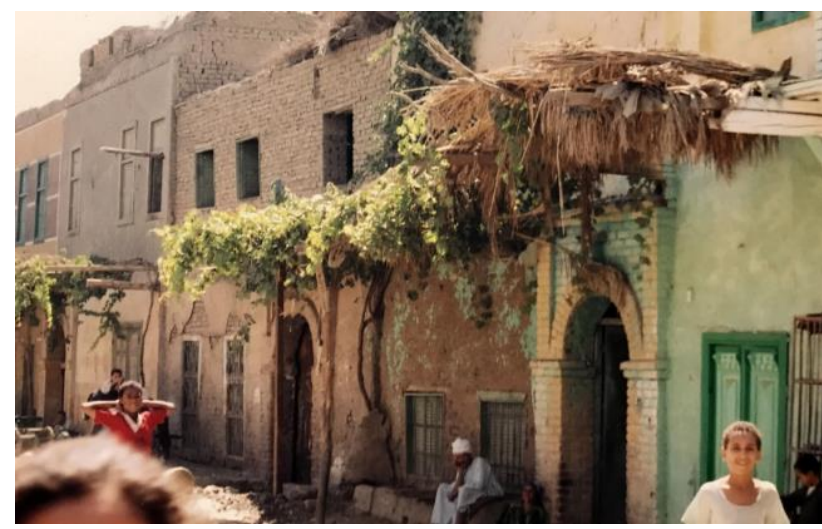

Figure 4. Two-story building, mud brick vernacular architecture in Lahun, (c) Author Image Copyright (2003).

\section{LAHUN VERNACULAR ARCHITECTURE}

The poor have no history, their dwellings are rarely documented, and the people who built them are soon forgotten. (Rudofsky ${ }^{6}, 1960$ 's ${ }^{7}$ ).

The modern Lahun village was developed in the vicinity of the pyramid in the 19th C. Until the beginning of the $21 \mathrm{st}$ Century, the modern architecture of the Lahun village followed ancestors' architecture. The main street, which goes through the entire village to lead to the Lahun pyramid, is not a straight line. It is approximately 950 meters long, and its width varies between 4 meters to 15 meters at different points. The photographic documentation of the village main street

\footnotetext{
6 Bernard Rudofsky (1905 - 1988) was a Moravian-born American writer, architect, collector, teacher, designer, and social historian. Guarneri, 2003.
}

done by the author in 2003, shows a mix of earthen and stone vernacular houses being dominant, with scattered concrete houses.

Two main vernacular typologies were identified:

1. Two-story houses which belonged to wealthy families. They consist of a ground floor in stone and the first floor in mud bricks, in most cases with carved wooden screens decorating the facades, creating privacy and fragmenting the sharp sunrays and softening the heat in the houses' interior.
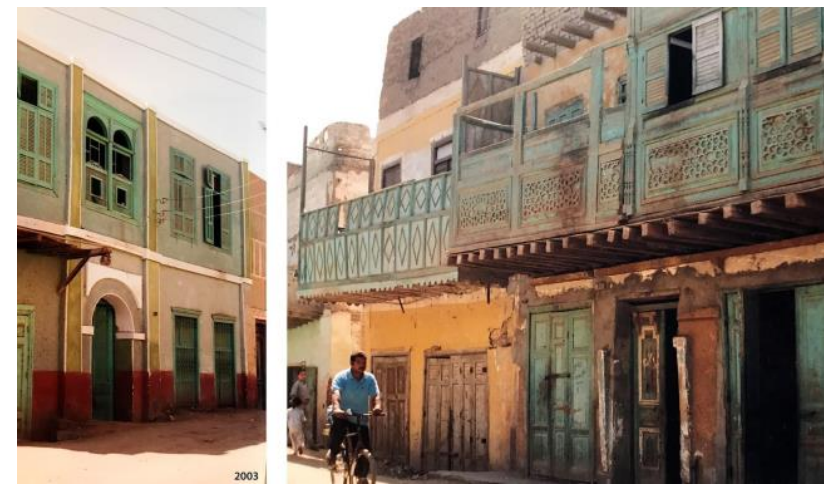

Figure 5. Two story buildings, vernacular architecture in Lahun, (C) Author Image Copyright (2003).

2. One or two-story houses which belonged to poorer families that consist of a ground floor in mud bricks. A grape vine tree was planted systematically in front of each house for the shade and to protect from the heat during the summer and vice-versa when the winter comes the vine loses all green leaves to clear the facade for the heat of the sun to warm up the interior.
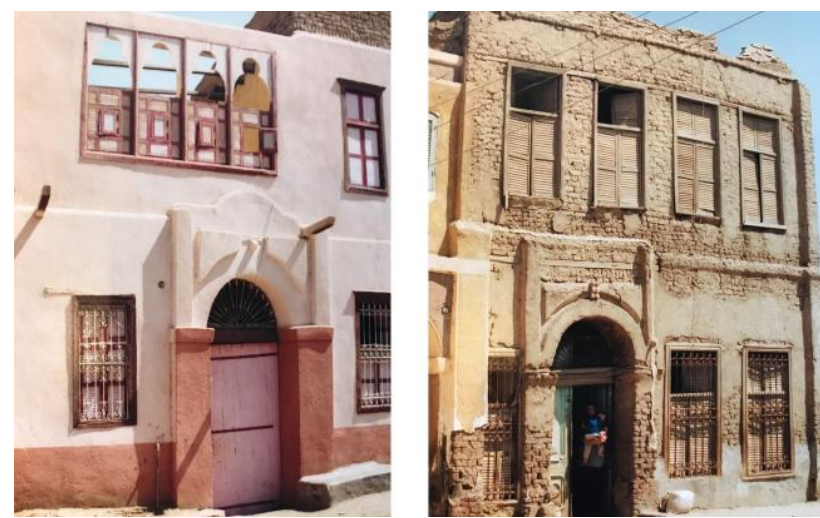

Figure 6. Building plastered and semi plastered mud brick vernacular architecture in Lahun,

(C) Author Image Copyright (2003).

In most cases, houses were plastered with a layer of mud to protect the mud brick and ease the process of the restoration by adding a new layer of mud plastering in case of erosions. In other cases, the plastering was done with a white lime layer which might be decorated with paintings illustrating the pilgrimage to Mecca or other traditional drawings.

Lahun was a small village in the 1950 's. Nowadays, the village became bigger because of the urban expansion and the increase of the population. According to the survey of the Central 
Agency for Public Mobilization and Statistics (CAPMAS), the village population in 2006 was 15,004 persons. There are 3,117 families from which 1,738 families were living in mud brick houses until 2006.

\subsection{Lahun Vernacular Architecture Survey in $\mathbf{2 0 1 0}$}

In 2010, along the village main street, the vernacular architectural typologies, and natural construction materials were still existing. The street lost part of the urban homogeneity that was still evident in 2003.

The author's documentation and urban survey of the Lahun main street in 2010 was based on an updated map using three overlapping layers:

1. The cadastral map of 1935 ,

2. Digitally traced aerial photo survey of 2002 CAPMAS $^{8}$

3. Site survey of the street buildings facades.

The urban survey analysis indicated the following results:

2.1.1 Vernacular Buildings and Building Materials: 35\% of the main street buildings were identified as vernacular houses in stone and/or mud brick (from which: $26 \%$ of houses had mud bricks ground floor, and $9 \%$ of houses had limestone ground floor) and $65 \%$ of buildings of the street were replaced by concrete buildings.

2.1.2 Buildings Heights: $77 \%$ are from 1 to 2 story buildings, $12 \%$ are 3 stories buildings, $11 \%$ are from 4 to 7 story buildings. The high-rise buildings disturb the village skyline and rural urban nature.

2.1.3 Buildings Conditions: $24 \%$ bad vernacular building condition, $11 \%$ fair vernacular building condition, $1 \%$ under construction, $27 \%$ fair contemporary building condition, $37 \%$ bad contemporary building condition.

2.1.4 Building Usage: The main use of buildings is for residential purposes with some commercial uses occupying the ground floors mainly in concrete buildings. Sometimes stores are created as a modern intervention in vernacular architecture houses.

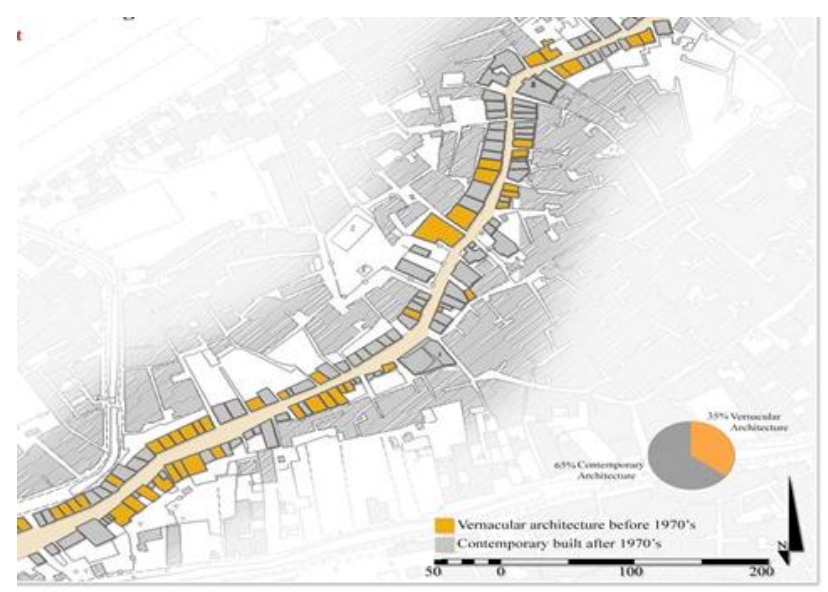

Figure 7. Map of the vernacular architecture survey in the main street of Lahun, (c) Author Image Copyright (2010).

8 CAPMAS, Central Agency for Public Mobilization and Statistics, Survey, 2006.

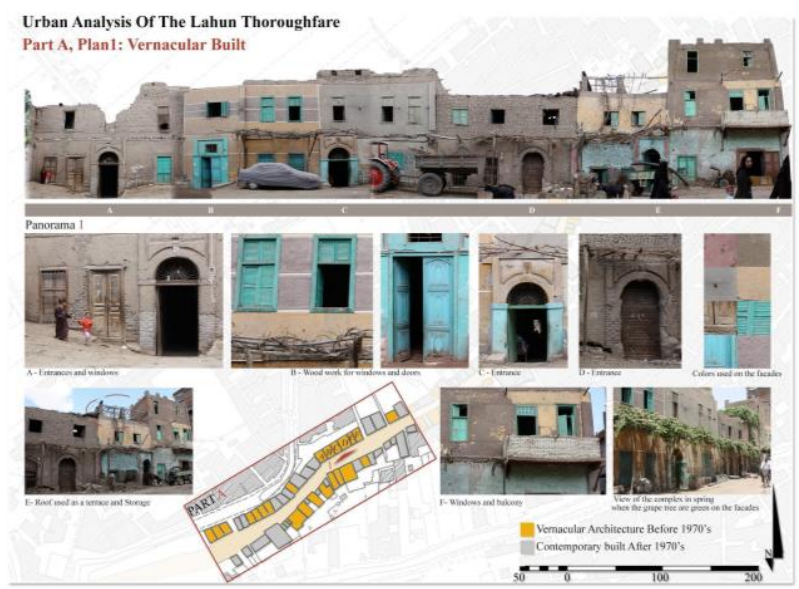

Figure 8. Pictures collage of some of the vernacular architecture in the main street of Lahun, (C) Author Image Copyright (2010).

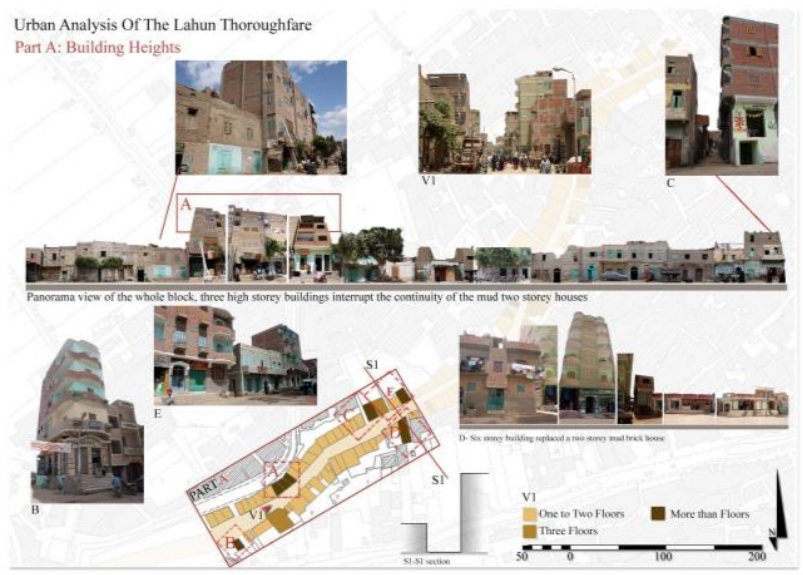

Figure 9. Pictures collage in part of the main street showing building heights, () Author Image Copyright (2010).

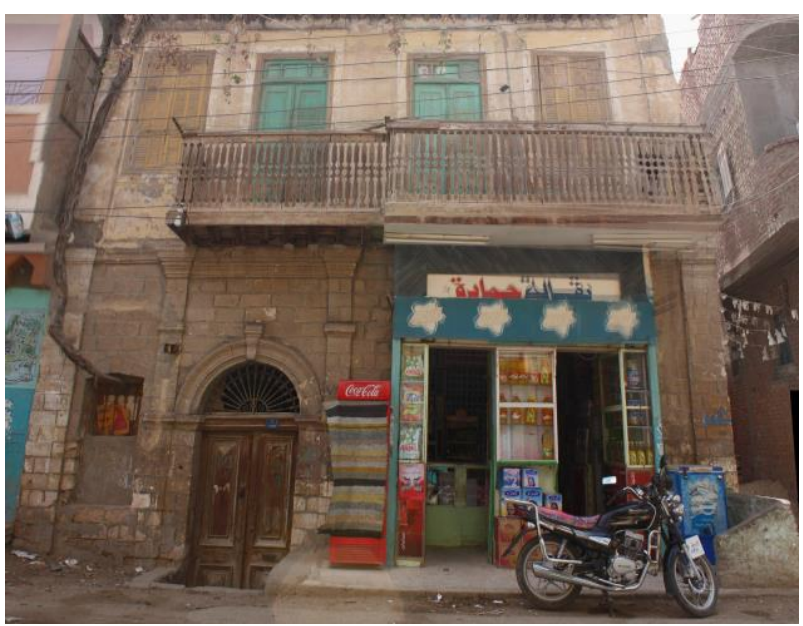

Figure 10. Two story building, plastered and semi plastered mud brick vernacular architecture in Lahun, (C) Author Image Copyright (2003).

In addition to the urban survey, the author conducted a photo documentation, and a survey of chosen vernacular houses facades in different spots in the street. The technology used is the total station. 
The study did not deal with the interior of the houses (some locals refused to give access and a number of vernacular houses were not inhabited thus not accessible).

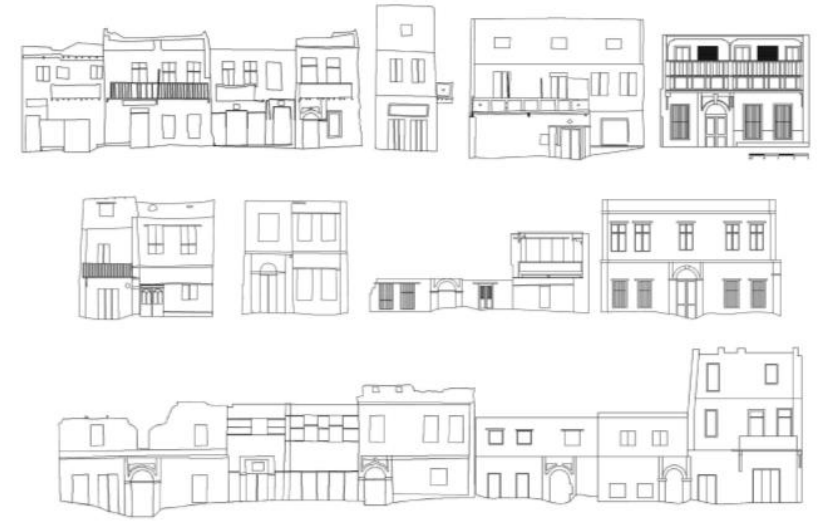

Figure 11. Architectural survey of a number of vernacular architecture houses in Lahun,

(C) Author Image Copyright (2010).

During the survey, the vernacular architecture heritage of Lahun was in danger and in bad condition. Lack of the local population's awareness about the value of vernacular heritage accelerated the demolition process. In the past decades, farmers dismantled their mud brick houses and constructed new ones in concrete as a symbol of wealth as well as responding to their contemporary needs related to the family expansion and to modern life.

There was no legislation for the protection of the vernacular architecture of Egyptian villages. Lack of control on the new constructions created urban problems and the loss of many vernacular heritage buildings. Excessive demolition of vernacular houses was occurring during the survey in 2010 and high-rise concrete buildings distort the skyline of the street.

After the Egyptian revolution in 2011 and for some years, the absence of the state's control demolition and construction aggravated the loss.

In the main street, rural features, vernacular urban morphology and vernacular architectural elements were still existing. Such as the mud brick benches 'mastaba' attached to the building's exterior and associated with social gatherings on the street. Climbing vines were still on the vernacular houses' facades of the street.

The village traditional food and goods market day and location kept their originality, on Monday of each week the market was taking place in the village entrance. But the market lacked handicraft products as well as the entertaining, such as storytelling.

The street was dusty, not clean and covered partly by asphalt and lacking garbage bins. The traffic was slow, not crowded but diverse. People, carts, handcarts, donkeys, cows, horses, bicycles, motorcycles, tricycles, cars and trucks all in little numbers but all share the street.

The 2010 author's study of the Lahun village main street proposed the urgent listing of the area for its particular value and suggested a detailed documentation of the vernacular heritage of the village as a first measure of protection. The Vernacular architecture presented a rare remaining representation of the local typology and the building techniques of the vernacular heritage of the region. Being the result of a historical trial and error process through generations performing this heritage, the conservation of vernacular houses was proposed as a main objective.

As for new constructions in the future, regulations for rural constructions should be drafted in order to revive the vernacular character. Regulations should be based on vernacular architectural typologies and traditional building techniques.

\section{THE LAHUN PYRAMID RE-OPENING, 2019}

After 130 years, the mud brick pyramid was opened to the public, for the first time, in June 2019 after a long process of restoration. Authorities built a new road, a highway that cuts the desert to reach the historical site plateau from the north without passing through the Lahun village. The decision was based on security reasons to avoid tourists entering the village and its narrow streets.
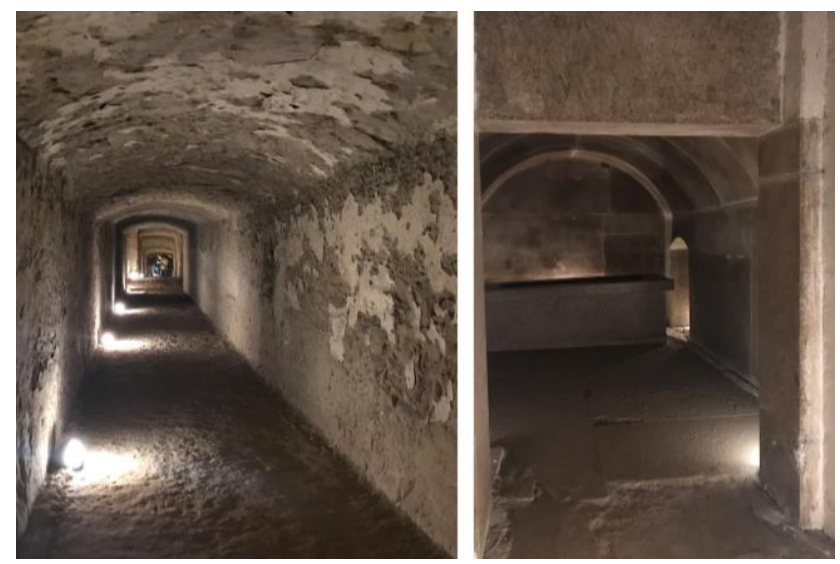

Figure 12. Lahun Pyramid from the inside after the restoration and the opening in June 2019,

(c) Author Image Copyright (2019).

With the re-opening of the pyramid after its long restoration, the local population should have benefited from the values of the heritage in the area. On the socio-economic level, new jobs for the youth and income generation should have depended on the historic site: tourism, scholars' visits, a museum for the Lahun history, services for visitors should all have been new sources of income generation. A school for vernacular architecture to create a new generation of vernacular builders, development of vernacular building handicrafts could also have been created with and for the local population of Lahun.

Improving living standards of the dwellings could have taken place, in parallel with raising awareness and knowledge of how and why vernacular architecture is environmentally friendly and includes high proportion of renewable and replaceable materials unlike concrete.

The village was the sole entrance to the historical site. To emphasize the continuity between the ancient Egyptian site and the village, the re-use of uninhabited vernacular dwellings was proposed, as a small museum, visitor and information centers welcoming tourists, visitors and scholars to the Lahun pyramid. Furthermore, Gisr Gadallah dyke, the link between the village and its pyramid, still needs urgent preservation especially since it is the zone where the village expansion occurs, and new illegal constructions take place. 


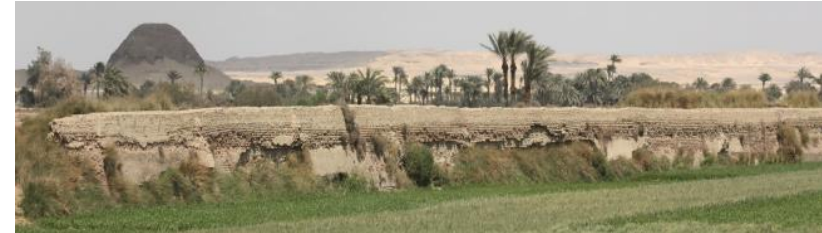

Figure 13. Lahun surrounding landscape, the Lahun pyramid and Gisr Gadallah mud brick barrage,

(c) Author Image Copyright (2010).

Lahun is the watergate to the Fayoum depression. And it is also the gate to the Lahun Pyramid, to Gisr Gadallah barrage, to the Kahun archaeological site, and to an exemplary vernacular heritage of the province that used to exist till recently. If the project had a name it would be called the 'EL Bawaba' which means 'The Gate' in Arabic.

Today, the Lahun village is a concrete forest, it lost the vernacular urban fabric and buildings. None of the houses documented in the 2010 survey still stands in the street except for three. The historical site did not benefit the people nor did the people needed to preserve the vernacular heritage to serve the historic site.

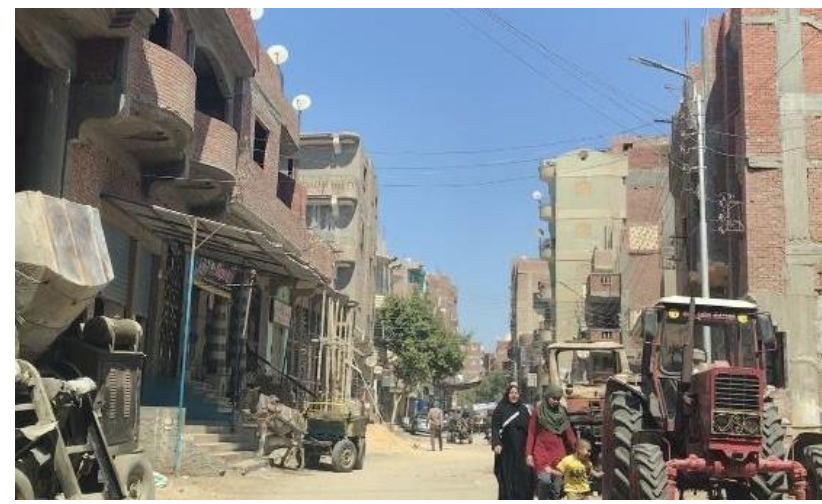

Figure 14. Lahun village main street,

(C) Author Image Copyright (2019).

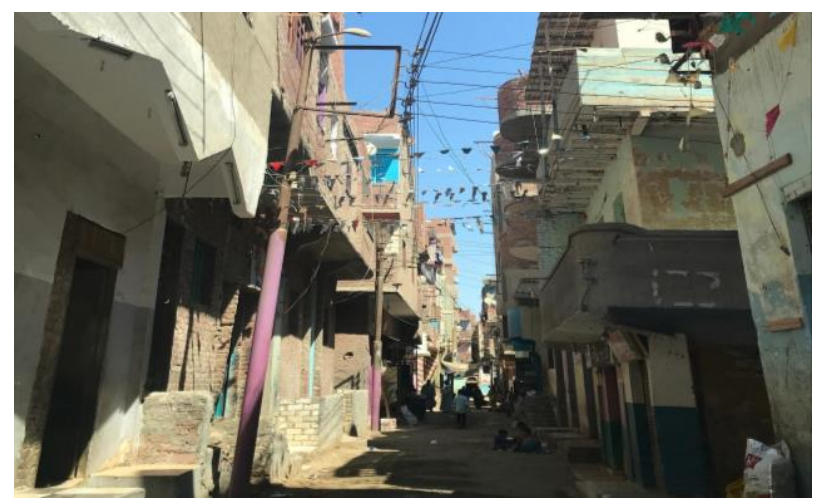

Figure 15. One of the streets of Lahun village,

(C) Author Image Copyright (2019).

Lahun's case in the oasis does not stand alone. In the last few decades, the vernacular architectural heritage loss was all over the oasis. The only exception is Tunis village, where traditional architectural techniques still occupy an important place in contemporary constructions.

\section{TUNIS VILLAGE 50 YEARS ON}

Not long before the beginning of the 20th Century, at the far North West of the Fayoum depression, on an elevated empty rocky land overlooking Lake Qarun, a small village began to exist. Local people tell the village story and explain that this was the result of the settlement of a wealthy family, Abd al Basseir family. The family started to cultivate and build the no-man land and brought local peasants and builders to work in the area. At the time, ownership laws did not regulate deserted land. The settlement grew to transform the area in a few decades, to become Tunis village.

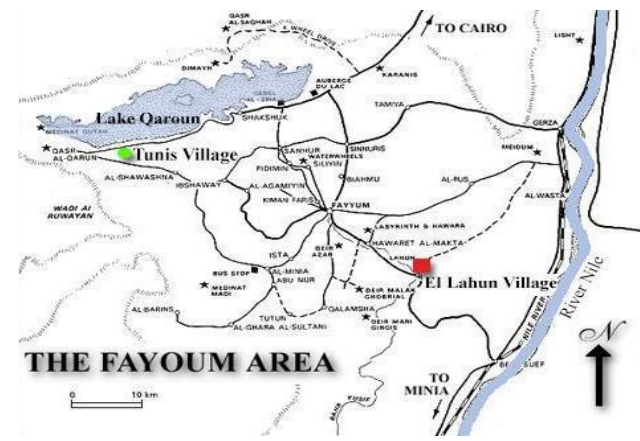

Figure 16. Sketch map of the Fayoum depression with the location of Tunis and Lahun village, Tour of Egypt Sites, 2009.

Tunis remained a hidden small village until the end of 1960's. It was a poor village. Its original vernacular architecture was simple adobe bearing walls. Palm tree beams were used for the roofing. Until the mid-1980s, there was no electricity and no tap water in houses. Women had to fill water basins from a single street tap. Until today the village lacks a proper sewage system. Unlike Lahun there are no monuments in the vicinity of the village.

During the 1960s and 70s, Evelyne Porret, a young Swiss pottery artist, came to visit Cairo with her family and fell in love with Egypt. A few years later, after several visits she decided to live in Fayoum. She explained "I wanted to own a place in a rural area, maybe close to Cairo, where I can produce my pottery." "She took her decision and bought a plot of land from Abdel-Basseir family in Tunis village. "Abdel Baseir pointed with his hand to show us roughly, and said, you can take this plot there" explained Porret how things were random and primitive. ${ }^{10}$

Porret was part of the intellectual scene in Cairo. Soon other artists and writers came to buy land in the same village where they built their countryside houses and workshops. The lake view and thousands of palm trees created an escape from crowded city life. At the time, none of them imagined that in 40 years, the village would become a well-known pottery village and a cultural hub, known by its traditional and vernacular architecture, and that it would include a big number of local pottery workshops, several hotels, an art museum, as well as desert safari, horseback riding and bird watching activities.

Back then, in the 1970s, these intellectuals, who chose Tunis as their second home, were aware of the beauty of the adobe rural vernacular architecture and chose to build their houses with the help of architects following an effective application of traditional construction systems and crafts. For example, Nessim Henin is the designer of the oldest part of Porret's house, who wrote one of the most relevant documentation of Egyptian villages, "Mari Girgis, Village de Haute-Egypte".

\footnotetext{
9 Author interview with Evelyne Porret

10 Ibid.
} 


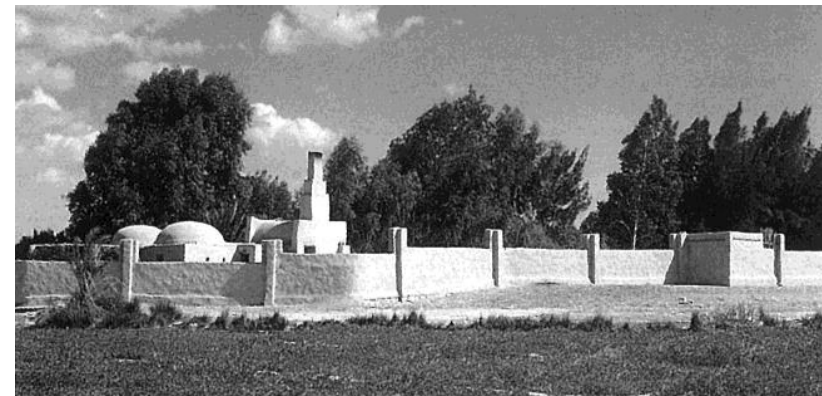

Figure 16. Porret's house in Tunis and the pottery workshop, 1990 ○ Musée De Saint -Amande-Les-Eaux, Evelyne Porret Michel Pastore, Potiers de France en Égypte- 1970-1990, 1990.

But at the same time, local peasants who had to travel and work for years in the oil rich Arab gulf states for economic reasons during the 1970 s and 1980 s, once back to Tunis, decided to replace the mud brick houses with concrete constructions. The fact being the poorer the family is the longer the vernacular survives.

Porret decided that her responsibility was to transfer her pottery techniques to the children of Tunis village. She explained that she was inspired by architect Wissa Wassef when she met him. Beside his magnificent work that revived the use of adobe architecture techniques in modern times, his school of tapestry, in the rural area of Harraneya, is a very successful project. Children and youth learn the weaving technique at the school and are then left to produce freely through their spontaneous creativity.

In 1989, she created an association and built her pottery school for local children next to her private workshop and house. Simple mud brick bearing walls workshops with beautiful vaults and domes open towards a large open space where there are mud basins, pottery kilns and ready to dry pottery. In the school there is also an outlet to sell the pottery for visitors.

After a few years, many of the school students created their own workshops and trained their family members to work in pottery. The village is now a well-known pottery village that hosts a big number of pottery workshops and shops. Other initiatives slowly emerged, artists opened cultural centers, architects worked with the locals for mud brick fabrication, new local tourism businesses appeared and more of traditional architecture was built with different approaches. Even during the post-2011 revolution and the economic crisis, Tunis continued to flourish unlike many other tourist areas in Egypt.

This does not imply that the situation in Tunis village is ideal regarding the vernacular heritage. Still local youth prefer concrete high-rise buildings when it comes to where they dream to live.

Ahmed Abdallah is a peasant and one of the most competent builders and contractors in Tunis who built a large number of houses and hotels for the village newcomers. He uses traditional building techniques with a lot of sensitivity and intuition. But when he built his own family house, next to his old adobe house, he replaced his old palm trees with a highrise concrete building. This was the request of his sons and grandsons as he explained.

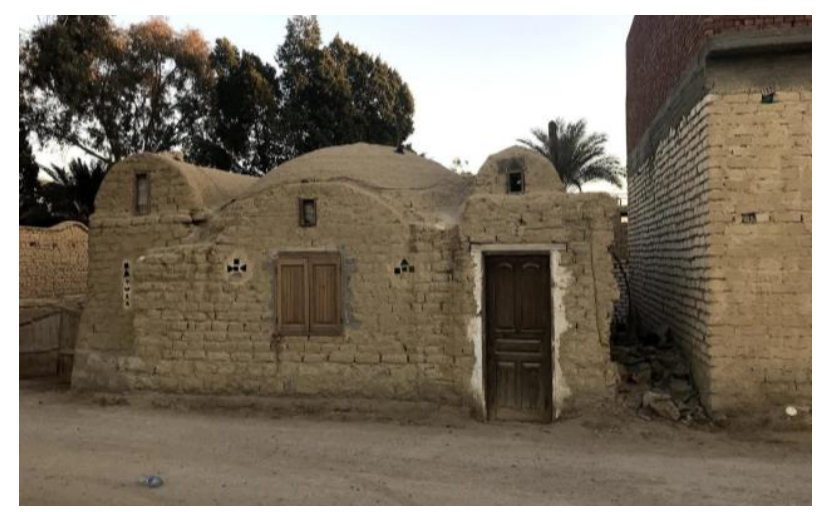

Figure 17. The old mud brick house of Ahmed Abdallah stands next to the new concrete building of his extended family's house, 1990 (C) Author picture, 2019.

The most important finding from Tunis experience is that many among the village inhabitants learned about the value of their inherited traditional building techniques and appreciate how the preservation of the rural and vernacular had a direct socioeconomic benefit on their lives and the lives of the coming generations.

\section{NOTES AND OBSERVATIONS}

Tunis village did not have a long history. It does not include monuments nor special vernacular heritage. But it became a unique village where the new architecture that is sympathetic to the traditional vernacular character was among the reasons for a better future for the village and its population. The village kept a simple and beautiful rural character and locals today stand in a better place on the socio-economic and cultural fronts.

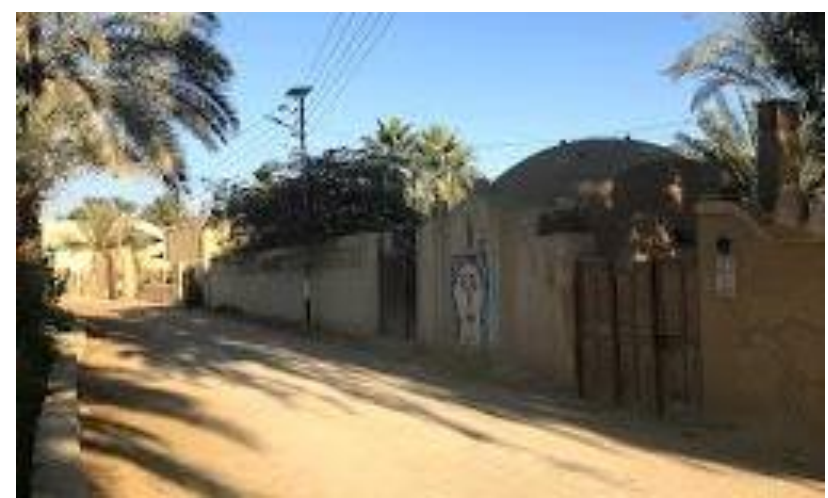

Figure 18. Tunis village main street, 2019

(C) Author picture, 2019.

In Lahun, authorities did not provide the protection of valuable vernacular heritage until it was lost. This happened because of lack of effective rural planning and building regulations. The state's heritage conservation policies prioritize restoration projects of ancient Egyptian sites as well as Islamic and Coptic monuments on the expense of vernacular heritage protection.

The archaeological site of Lahun is a successful restoration project but lacks the conservation approach of the village. Giving the people the chance to benefit from their heritage by emphasizing the link between the village and the historical site would have been a better decision than constructing a new road to reach the pyramid and avoid passing through the village. 
On the other hand, the village's vernacular nature revival can be of great benefit to the tourist experience. This could be done by protecting the remaining traces of built vernacular heritage. Recreating the link to the archaeological site, by developing a rehabilitation project that includes enhancement of existing concrete buildings, and improving street conditions, and integrating the community in projects catering to what is lacking in the village (schools, health care, community services, handicrafts, tourist services ...etc.). When decision-makers work towards the well-being of people, people appreciate living better in their environment.

The intangible vernacular heritage is more solid than the built vernacular heritage. Beliefs and traditions, feasts and markets, traditional food and crafts, are elements that can play a role in Lahun's rehabilitation.

The loss of vernacular architecture can be reversed if communities believe that following traditional techniques, in constructing their future dwellings, does indeed offer economic, social and environmental benefits.

\section{REFERENCES}

Ayrout, H. H., 2005: The Egyptian Peasant, 1938. AUC Press.

Blackman, W.S., 2000: The Fellahin of Upper Egypt, 1927, Chapter: The village and their inhabitants. AUC Press.

Capmas, Central Agency for Public Mobilization and Statistics, Survey of 2006.

El Sayyad, N., 2006: Vernacular Architecture in the $21^{s t} c$, Theory, Education and Practice. Taylor \& Francis.

Guarneri, A. B., 2003: Bernard Rudofsky: A Humane Designer. Springer-Verlag, Wien.

Hassan, F. A., 2005: River Runs Through Egypt: Nile Floods and Civilization. Geotimes.

Hassan, F., 1969, 4th ed., 2004: "Architecture for the poor. AUC Press.

Hewison, R. N., 2001, 3rd ed., 2006: The Fayoum History and Guide. AUC press.

ICOMOS, 1993: Vernacular architecture, International Scientific Committee On Vernacular Architecture, Colombo. ICOMOS.

Lambercy, P., 1990: Evelyne Porret - Michel Pastore, Potiers de France en Egypte- 1970-1990, Edition Conseil General du Departement du Nord Ville de De Saint - Amand- Les-EauxMusée.

Nessi, H., 2001: Mari Girgis, Village de Haute-Egypte, Institut Francais d'Archeologie Oriental, IFAO.

Quirke, S., 2005: Lahun, a Town in Egypt 1800 BC, and The History of Its Landscape. London.

Vivian, C., 2000: The Western Desert of Egypt, An explorer's Handbook. AUC Press.

William Lane, E., (1801-1876), 2000: Description of Egypt, Edited and with an introduction by Jason Thompson. AUC Press. 